\title{
Kepercayaan Diri Siswa Dan Pengaruhnya Terhadap Keterampilan Berbicara Bahasa Inggris
}

\author{
Adhityo Kuncoro ${ }^{1}$, Fajar Erlangga ${ }^{2}$ dan Randi Ramliyana ${ }^{3}$ \\ 1,2,3 Program Studi Teknik Informatika, Universitas Indraprasta PGRI, Jl. Raya Tengah No.80, \\ Jakarta Timur. Indonesia.13760. \\ Correspondence: Adhityo Kuncoro (adhityokuncoro@yahoo.com) \\ Received: 170721 - Revised: 190721 - Accepted: 230721 - Published: 261021
}

\begin{abstract}
Abstrak. Penelitian ini dilakukan untuk mengetahui kepercayaan diri siswa serta pengaruhnya terhadap keterampilan berbicara bahasa Inggris mereka. Penelitian yang menggunakan metode survey ini dilaksanan di Universitas Indraprasta PGRI, dengan 40 responden yang dipilih secara acak dari dua kelas berbeda dari tiga kelas mahasiswa semester dua yang ada. Penelitian ini menggunakan tes tertulis untuk memperoleh data. Data tersebut kemudian diproses menggunakan program SPSS 2.0 dan dianalisis menggunakan analisis regresi dan korelasi. Hasil dari penelitian menunjukkan bahwa kepercayaan diri memiliki pengaruh yang signifikan terhadap keterampilan berbicara bahasa Inggris siswa, terlihat dari nilai $s i g=0,000($ nilai $s i g<0,05)$ dan $t_{\text {hitung }}=4,882$ ( $t_{\text {hitung }}$ lebih besar dari $t_{\text {tabel }}=1,69$ ). Kesimpulannya, hasil dari penelitian ini membuktikan bahwa kepercayaan diri siswa memiliki pengaruh terhadap keterampilan berbicara bahasa Inggris.
\end{abstract}

Kata Kunci: kepercayaan diri, bahasa Inggris, siswa

Citation Format: Kuncoro, A., Erlangga, F., \& Ramliyana, R. (2021). Kepercayaan Diri Siswa Dan Pengaruhnya Terhadap Keterampilan Berbicara Bahasa Inggris. Prosiding Seminar Nasional Abdimas Ma Chung (SENAM), 2021, 131-141 


\section{PENDAHULUAN}

Di dalam standar kompetensi dan kompetensi dasar mata pelajaran bahasa Inggris, ada beberapa aspek kemampuan berbahasa yang harus dikuasai oleh siswa. Aspek tersebut meliputi kegiatan mendengarkan, berbicara, membaca dan menulis. Keempat aspek ini merupakan dasar yang harus dipenuhi siswa agar memiliki kompetensi berbahasa Inggris yang baik. Dari keempat aspek tersebut kemampuan berbicara dalam bahasa Inggris seringkali dianggap sebagai ukuran apakah seorang siswa sudah dapat menggunakan dengan bahasa Inggris dengan baik atau belum. Lebih lanjut, memiliki kemampuan berbicara dalam bahasa Inggris sudah menjadi hal yang sangat penting dewasa ini, apalagi materi pelajaran bahasa Inggris sudah diajarkan kepada siswa sejak mereka berada di bangku sekolah menengah ke bawah.

Ada banyak faktor yang dapat mempengaruhi kemampuan siswa dalam memiliki kemampuan berbicara dalam bahasa Inggris. Beberapa dari faktor tersebut bahkan membuat kebanyakan dari siswa enggan berbicara dalam bahasa Inggris saat menghadapi situasi percakapan yang mengharuskan mereka menggunakannya, misalnya pada saat mereka bertemu dengan orang asing yang menggunakan bahasa Inggris. Beberapa dari mereka cenderung untuk menghindari kontak langsung karena merasa tidak percaya diri untuk berbicara dalam bahasa Inggris. Dengan kata lain, salah satu faktor utama yang menghambat perkembangan kemampuan berbicara bahasa Inggris mereka adalah adalah kurangnya rasa percaya diri untuk berbicara dalam bahasa Inggris, padahal kepercayaan diri tersebut mempunyai pengaruh yang sangat besar terhadap kemampuan mereka. Hal ini sejalan dengan pendapat Komara yang menyatakan bahwa rasa percaya diri yang dimiliki siswa nantinya akan mengembangkan bakat, minat, dan potensi yang sebenarnya mereka sudah miliki sebelumnya sehingga bisa berkembang menjadi sebuah keberhasilan. Siswa yang dengan kepercayaan diri yang tinggi memliki kecenderungan untuk lebih baik dalam merencanakan karirnya dibandingkan siswa dengan kepercayaan diri yang rendah (2016).

Meskipun pihak guru sebagai pendidik sudah maksimal dalam mendorong mereka untuk aktif dan percaya diri dalam pelajaran bahasa Inggris, namun jika para siswa tidak berupaya untuk meningkatkan kepercayaan diri mereka tentu saja kemajuan mereka tidak akan signifikan. Kepercayaan diri ini tidak muncul dengan 
sendirinya, namun itu akan timbul melalui proses pembelajaran yang dilakukan oleh siswa. Kepercayaan diri merupakan sebuah keyakinan seseorang terhadap diri dan kemampuan dirinya sendiri. Dengan adanya keyakinan ini, seseorang akan mampu mengambil sebuah keputusan dalam melakukan sesuatu dengan rasa tanggung jawab (Baharudin dan Wahyuni, 2015:216). Semakin besar rasa percaya diri siswa maka semakin besar pula tekad mereka untuk memperdalam ilmu yang sedang mereka pelajari. Dengan rasa percaya diri, siswa dapat lebih leluasa berbicara dan mengasah keterampilan berbahasa mereka.

Rasa percaya diri menjadi modal bagi siswa untuk berani mempelajari hal yang bahkan dianggap sulit, misalnya menggunakan beberapa idiom, ekspresi maupun kosakata yang tepat dan sesuai dengan konteks percakapan. Mardatillah (2010: 176) menyatakan bahwa kepercayaan diri yang dimiliki seseorang dapat dilihat dari sikap: 1. Mengenal dengan baik kekurangan dan kelebihan yang dimilikinya lalu mengembangkan potensi yang dimilikinya, 2. Membuat standar atas pencapaian tujuan hidupnya lalu memberikan penghargaan jika berhasil dan bekerja lagi jika tidak tercapai, 3. Tidak menyalahkan orang lain atas kekalahan atau ketidak berhasilannya namun lebih banyak instrospeksi diri sendiri,4. Mampu mengatasi perasaan tertekan, kecewa, dan rasa ketidak mampuan yang menghingapinya, 5. Mampu mengatasi rasa kecemasan dalam dirinya, 6. Tenang dalam menjalankan dan menghadapi segala sesuatunya, 7. Berpikir positif dan;8. Maju terus tanpa harus menoleh kebelakang.

Meskipun demikian, di Indonesia sendiri, kepercayaan diri dalam menggunakan bahasa Inggris masih menjadi permasalahan utama bagi banyak siswa. Kebanyakan dari mereka merasa tidak percaya diri untuk berbicara dalam bahasa Inggris karena mereka merasa kemampuan gramatikal dan perbendaharaan kosakatanya masih terbatas. Beberapa dari mereka merasa enggan bahkan malu pada saat diberikan kesempatan untuk berbicara dalam bahasa Inggris dengan alasan tidak percaya diri dengan kemampuan berbicara yang mereka miliki. Karena itulah tidak heran, jika keterampilan berbicara dalam bahasa Inggris merupakan aspek yang seringkali menimbulkan rasa takut saat para siwa akan mempraktikkannya.

Keterampilan berbicara diartikan sebagai kemampuan seseorang dalam menyusun kalimat-kalimat yang merupakan syarat terjadinya komunikasi. Melalui 
kalimat-kalimat tersebut perbedaan tingkah laku yang berbeda dan bervariasi dari setiap masyarakat dapat ditampilkan (Saputra, 2017). Apabila siswa telah mempunyai keterampilan berbicara yang baik, mereka akan mampu mengomunikasikan ide-ide mereka ketika mereka berada di sekolah maupun di sekitar penutur asing. Keterampilan ini juga dapat menjaga hubungan baik antara mereka dan orang lain (Hotmaria, 2021). Keterampilan berbicara adalah sebuah kemampuan untuk dapat berbicara dengan mahir dan lancar ketika menyatakan berbagai hal dalam pikiran atau berbagai gagasan. Kemampuan ini dapat dikembangkan oleh pembicara dengan cara menguasai kosa kata, mempraktikan pengucapan yang tepat, dan memiliki kepercayaan diri dalam berbicara (confidence speaking). Kemampuan seseorang untuk berbicara dengan kepercayaan diri yang baik merupakan tahap awal dalam menyampaikan gagasan secara mendetail dan lebih terurai, serta tanpa rasa takut dalam mengungkapkanya (Yulianto, 2021).

Dari penjelasan-penjelasan yang telah diuraikan sebelumnya, peneliti menduga adanya keterkaitan antara rasa percaya diri yang dimiliki siswa dengan keterampilan berbicara dalam bahasa Inggris mereka. Oleh karena itu, peneliti tertarik untuk membuktikan secara ilmiah pengaruh antara kepercayaan diri siswa terhadap ketrampilan berbicara bahasa Inggris melalui penelitian yang berjudul "rasa percaya diri siswa dan pengaruhnya terhadap keterampilan berbicara dalam bahasa Inggris". Penelitian ini diharapkan dapat bermanfaat sebagai referensi kajian keilmuan untuk penelitian lain di bidang yang sama, khususnya bidang kebahasaan.

\section{MASALAH}

Keterampilan berbicara merupakan salah satu kompetensi dasar yang memerlukan penguasaan aspek bahasa yang kompleks. Fitriani (2015) mengatakan bahwa pada saat berbicara, seseorang membangun ide/gagasan yang dituangkan ke dalam kata-kata yang mewakili persepsi, perasaan, dan maksud tujuan dari si pembicara sehingga semua yang disampaikan lebih bermakna. Pembicara tentu tidak hanya sekedar asal menyatukan beberapa kata, namun mereka merangkainya menjadi satu kesatuan yang memiliki makna dan mewakili maksud tujuan/gagasan mereka.

Salah satu kesulitan yang dialami saat berbicara dalam bahasa Inggris adalah kurangnya rasa percaya diri dan gangguan kecemasan. Fitirani (2015) mengatakan bahwa pada saat berbicara bisa saja muncul rasa tidak percaya diri, cemas, malu, 
grogi dan khawatir. Jika mereka tidak memercayai kemampuan mereka sendiri, maka semua masalah tersebut akan muncul pada saat berbicara. Peneliti berfokus pada variabel rasa percaya diri dari sekian banyak faktor yang memengaruhi keterampilan berbicara. Peneliti ingin membuktikan secara ilmiah kaitan rasa percaya diri dengan keterampilan berbicara. Hasil dari penelitian ini diharapkan menjadi salah satu referensi untuk kajian penelitian lanjutan dalam mencari solusi mengatasi kesulitan berbahasa Inggris di lingkungan mahasiswa teknik informatika Universitas Indraprasta PGRI Jakarta.

\section{METODE PELAKSANAAN}

Penelitian ini dilaksanakan di Universitas Indraprasta PGRI, dengan populasi yaitu seluruh mahasiswa semester dua yang menjadi peserta didik di dua kelas reguler pada program studi Teknik Informatika. Dari populasi tersebut, 40 mahasiswa dipilih sebagai sampel menggunakan teknik pengambilan sampel secra random. Metode penelitian yang digunakan dalam peneltian ini adalah metode survey. Data untuk penelitian ini diperoleh dengan menggunakan tes lisan dan angket atau kuesioner.

\section{Tes lisan}

Tes lisan berbentuk role play/percakapan digunakan untuk mendapatkan data sehubungan dengan keterampilan berbicara siswa dalam bahasa Inggris. Penilaian dilakukan oleh peneliti selaku dosen mata kuliah yang bersangkutan. Teknik ini digunakan untuk mengukur keterampilan berbicara. Tes ini berbentuk tes perbuatan (praktek). Tes tersebut dilakukan dengan bermain peran (role play) yang mengharuskan mahasiswa melakukan percakapan dengan situasi dan ungkapan berdasarkan materi yang sudah dipelajari. Penilaian tes ini didasari oleh 5 kriteria, yaitu struktur kalimat (grammar), kosakata(vocabulary), pemahaman (comprehension), kelancaran (fluency), dan pelafalan (pronounciation).

\section{Angket atau kuesioner}

Teknik ini digunakan untuk mendapatkan data tentang rasa percaya diri siswa yaitu dengan kuesioner skala. Kuesioner adalah sejumlah pertanyaan tertulis yang digunakan dalam arti laporan tentang pribadinya, atau hal-hal yang diketahui (Arikunto 1993:124). Angket yang diberikan kepada mahasiswa dikembangkan berdasarkan kisi-kisi angket rasa percaya. Penilaian pada angket tersebut didasari 
oleh tiga indikator yang meliputi: keyakinan diri, sikap positif dan memanfaatkan kelebihan. Penilaian terhadap kepercayaan diri siswa diukur menggunakan skala likert dengan lima rentangan intensitas dari jawaban yang tersedia yaitu selalu/sering sekali, sering, kadang-kadang, sangat jarang, dan tidak pernah.

Data hasil survei tersebut kemudian dianalisis dengan menggunakan:

\section{Teknik Analisis deskriptif}

Data yang diperoleh dari hasil penelitian selanjutnya ditabulasikan untuk dianalisis sesuai dengan arah dan tujuan penelitian. Tabulasi tersebut terdiri dari tabel deskripsi data angket. Tabel hasil dianalisis dengan menghitung rata-rata, median, simpangan baku, interval, dan tabel frekuensi data.

\section{Teknik Pengujian Persyaratan Data}

Pengujian persyaratan analisis yang digunakan yaitu:1. Uji normalitas dengan menggunakan liliefors. Data dinyatakan normal jika harga $\mathrm{F}_{\text {hitung }}<\mathrm{F}_{\text {tabel }}$ diuji dengan taraf signifikansi $\alpha=0,05$. sedangkan data linear apabila $F_{\text {hitung }}<F_{\text {tabel }}$ diuji dengan taraf signifikansi $\alpha=0,05 ; 2$. Uji homogenitas varians dimaksudkan untuk menguji kesamaan varians populasi yang berdistribsui normal. Uji homogenitas menggunakan uji Bartlett. Varians dinyatakan homogen jika $F_{\text {hitung }}<F_{\text {tabel }}$ diuji dengan taraf signifikan $\alpha=0,05$. 3. Uji linearitas data keberartian regresi dimaksudkan untuk melihat apakah regresi yang diperoleh berrati apabila dipergunakan untuk membuat kesimpulan antar variable "anova", regresi linier apabila $\mathrm{F}_{\text {hitung }}<\mathrm{F}_{\text {tabel }}$ diuji dengan taraf signifikasi $\alpha=0,05$. 


\section{HASIL DAN PEMBAHASAN}

Data dari survei selanjutnya diproses menggunakan komputer, dengan menggunakan program SPSS 2.0. Data dari seluruh responden ditampilkan secara statistik pada tabel 1 berikut.

Tabel 1. Deskripsi statistik variable Kepercayaan Diri (X) dan Keterampilan Berbicara(Y)

\begin{tabular}{l|l|l}
\hline \multicolumn{1}{c|}{ Valid } & $\mathrm{X}$ & $\mathrm{Y}$ \\
$\mathrm{N}$ & 40 & 40 \\
& & \\
Mean & 0 & 0 \\
Median & 89.0750 & 17.6500 \\
Mode & 90.5000 & 18.0000 \\
Std. Deviation & 80.00 & 20.00 \\
Variance & $12 / 40014$ & 2.87830 \\
Skewness & 153.765 & 8.285 \\
Std. Error of Skewness & -.024 & -.119 \\
Kurtosis & .374 & .374 \\
Std. Error of Kurtosis & .373 & .296 \\
Range & .733 & .733 \\
Minimum & 62.00 & 13.00 \\
Maximum & 60.00 & 12.00 \\
\hline
\end{tabular}




\section{Analisis data variable X (Kepercayaan Diri)}

Tabel 1 di atas menunjukkan bahwa nilai maksimum dari variable $\mathrm{X}$ adalah 122 sedangkan nilai minimumnya adalah 60 . Nilai beda maksimum dan minimum atau yang biasa disebut range/jangkauan untuk variable $X$ adalah 62 . Nilai rata-rata/mean variable $X$ ini adalah 89,07, sedangkan untuk nilai median/nilai tengahnya adalah 90,5. Angka ini menunjukkan bahwa 50 persen siswa mempunyai nilai yang lebih kecil dari nilai median tersebut. Selain itu, perbedaan antara nilai rata-rata dan nilai tengah yang tidak begitu jauh (mean=89,07 dan median=90,5) menunjukkan bahwa data rasa percaya diri cukup representatif. Berdasarkan angka yang tertera pada modus, mayoritas siswa mempunyai jumlah nilai 80 untuk variable $\mathrm{X}$.

Menurut ukuran disperse dengan ukuran standar deviasi menunjukkan bahwa variable X memiliki nilai sebesar 12,4. Sedangkan tingkat heterogen dari variable X dapat kita lihat dari angka yang tertera di kolom variance, yaitu sebesar 153,76. Kemudian jika dilihat dari distribusinya, angka statistic menunjukkan bahwa variable $\mathrm{X}$ mempunyai distribusi menceng ke kiri yang ditandai oleh nilai skewness negatif sebesar -0,024 (lihat gambar 4.2). Dan jika dilihat keruncingannya atau kurtosisnya, menunjukkan bahwa variable $\mathrm{X}$ meruncing karena nilai kurtosisnya positif sebesar 0,37. Berikut adalah histogram data variable $\mathrm{X}$ (Rasa percaya diri).

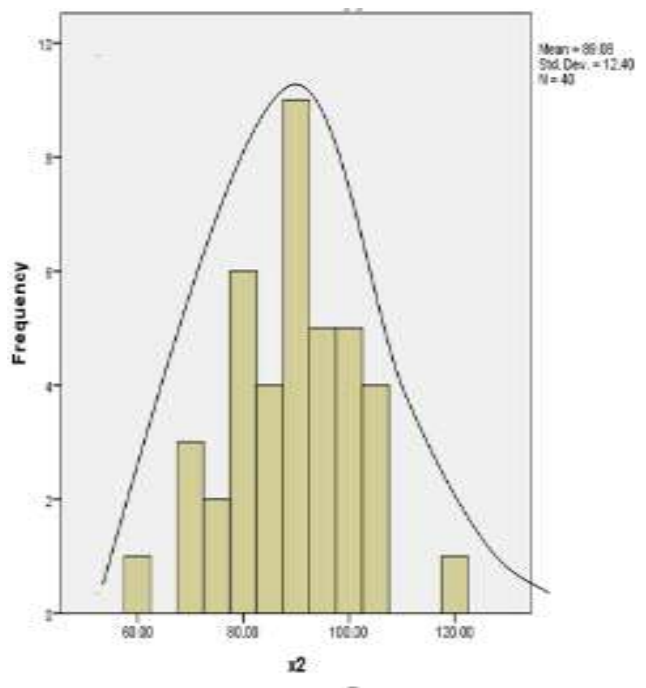

Gambar 1. Histogram data skor rasa percaya diri

Dari tabel distribusi, histogram dan polygon frekuensi (Gambar 1) diatas dapat disimpulkan bahwa data skor rasa percaya diri siswa dalam penelitian ini cenderung 
terdistribusi normal.

\section{Analisis data variable $\mathbf{Y}$ (Keterampilan berbicara)}

Dari deskripsi pada tabel 1 di atas kita dapat melihat bahwa variable Y (Keterampilan Berbicara) memiliki nilai maksimum sebesar 25, sementara nilai minimumnya 12. Perbedaan nilai maksimum dan minimum untuk variable Y adalah 13. Selain itu, variabel juga memilliki nilai mean sebesar 17,65 dan nilai median sebesar 18 . Nilai ini mengindikasikan bahwa sejumlah 50 persen dari mahasiswa mempunyai nilai yang lebih rendah dari nilai median yang tertulis. Kemudian, nilai rata-rata dan nilai tengah memiliki selisih yang tidak begitu jauh (mean=17,65 dan median=18). Hal megindikasikan bahwa perbedaan antara data keterampilan berbicara sudah cukup mewakili. Dari angka yang terlihat pada modus, kebanyakan mahasiswa memperoleh nilai 20 untuk variabel Y. Ukuran disperse menggunakan ukuran standar deviasi meperlihatkan nilai sebesar 2,87 untuk variabel $\mathrm{Y}$. Untuk tingkat heterogen dari variable $\mathrm{Y}$, kita bisa mengetahuinya dari angka di kolom variance, yaitu senilai 8,28. Berdasarkan distribusinya, angka statistik yang ada memeperlihatkan bahwa variable $\mathrm{Y}$ memilliki distribusi yang condong ke kiri yang dapat diketahui dengan melihat nilai skewness negatif sebesar -0,11 (lihat gambar 2). Kemudian, berdasarkan tingkat keruncingan atau kurtosisnya, variabel $\mathrm{Y}$ cenderung meruncing karena nilai kurtosisnya yang positif sebesar 0,29. Di bawah ini adalah histogram untuk data variabel Y.

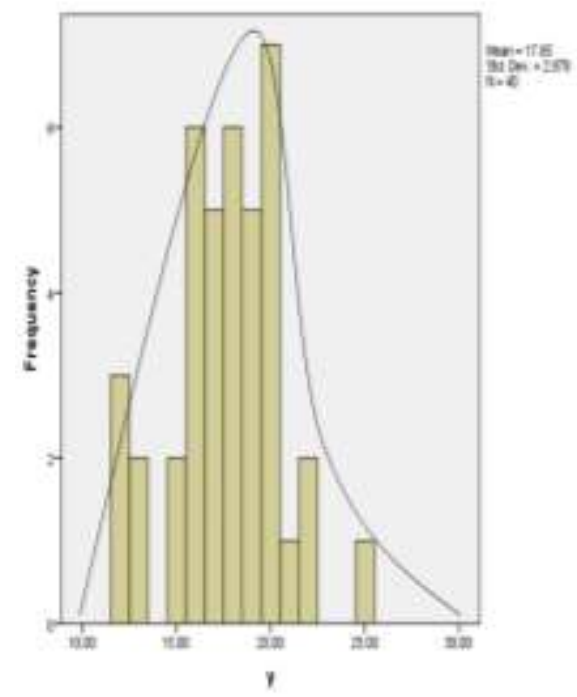

Gambar 2. Histogram data skor keterampilan berbicara siswa

Dari tabel distribusi, histogram dan polygon frekuensi dapat disimpulkan bahwa data nilai keterampilan berbicara dalam bahasa Inggris siswa pada penelitian ini memiliki 
kecenderungan untuk terdistribusi secara normal.

\section{Pengujian linieritas garis regresi}

Pengujian linieritas dalam penelitian ini digunakan hipotesis berikut:

$\mathrm{H}_{0}$ : garis regresi hubungan antara variable $\mathrm{X}$ dan variable $\mathrm{Y}$ linier

$\mathrm{H}_{1}$ : garis regresi hubungan antara variable $\mathrm{X}$ dan variable $\mathrm{Y}$ tidak linier

Perhitungan dilakukan dengan bantuan computer melalui program SPSS 2.0. Sesuai dengan ketentuan yang berlaku pada program tersebut, criteria dari normalitas data terpenuhi jika $p$ value ( $\operatorname{sig})>0,05\left(\mathrm{H}_{0}\right.$ diterima). Jika $\mathrm{H}_{0}$ diterima maka garis regresi tersebut linier. Nilai sig adalah bilangan yang tertera pada kolom sig baris Deviation from Liniearity dalam tabel ANOVA hasil perhitungan pengujian linieritas garis regresi oleh program SPSS.

\section{Linieritas garis regresi hubungan $\mathrm{X}$ dengan $\mathrm{Y}$}

Hasil perhitungan pengujian linieritas garis regresi hubungan antara variable $\mathrm{X}$ dengan variable Y dapat dilihat pada tabel 2.

Tabel 2. Rekapitulasi Hasil Pengujian Linieritas Garis Regresi Hubungan Antara Variable $\mathrm{X}$ dengan Variable $\mathrm{Y}$

\begin{tabular}{|c|c|c|c|c|c|}
\hline & Sum of Squares & Df & $\begin{array}{l}\text { Mean } \\
\text { Square }\end{array}$ & F & Sig. \\
\hline (Combined) & 246.933 & 28 & 8.819 & 1.274 & .348 \\
\hline $\begin{array}{l}\text { Between Linearty } \\
\text { Groups }\end{array}$ & 158.864 & 1 & 158.864 & 22.943 & .001 \\
\hline $\begin{array}{l}\text { Deviation from } \\
\text { linearty }\end{array}$ & 88.069 & 27 & 3.262 & .471 & .946 \\
\hline $\mathrm{Y}^{*} \mathrm{x}$ & & & & & \\
\hline Within Groups & 76.167 & 11 & 6.924 & & \\
\hline Total & 323.100 & 39 & & & \\
\hline
\end{tabular}

Dari tabel di atas dapat kita lihat bahwa nilai pada kolom sig baris Deviation from Linearity adalah 0,946 lebih besar dari 0,05 sehingga $\mathrm{H}_{0}$ diterima dan hal ini mengartikan bahwa garis regresi antara variable $\mathrm{X}_{2}$ dan variable $\mathrm{Y}$ tersebut adalah linier. 


\section{KESIMPULAN}

Hasil perhitungan dan analisis terhadap data menunjukkan bahwa kepercayaan diri yang dimiliki siswa memiliki pengaruh yang signifikan terhadap keterampilan berbicara bahasa Inggris mereka. Hal ini dapat diketahui dari nilai $s i g=0,000$ (nilai $s i g<0,05$ ) dan $t_{\text {hitung }}=4,882$ ( $t_{\text {hitung }}$ lebih besar dari $t_{\text {tabel }}=1,69$ ). Dengan kata lain, hasil dari penelitian ini membuktikan bahwa kepercayaan diri siswa memiliki pengaruh terhadap keterampilan berbicara bahasa Inggris. Dengan hasil ini, dapat dilakukan penelitian lanjutan terkait dengan solusi pembelajaran khususnya keterampilan berbicara dalam bahasa Inggris.

\section{UCAPAN TERIMA KASIH}

Peneliti mengucapkan terima kasih kepada Kepala Program Studi Teknik Informatika Universitas Indraprasta PGRI dan jajarannya yang telah memberikan izin melakukan penelitian di lingkungan kampus. Peneliti juga mengucapkan terima kasih kepada peneliti lain yang telah menjadi sumber referensi dalam penelitian ini.

\section{DAFTAR PUSTAKA}

Baharudin, \& Esa Nur Wahyuni. 2015. Teori Belajar dan Pembelajaran. Yogyakarta: Ar-Ruzz Media

Fitriani, Dea Aries., Apriliaswati, Rahayu., Wardah. 2015. A Study on Student's English Speaking Problems In Speaking Performance. Jurnal Pendidikan dan Pembelajaran Khatulistiwa, Vol 4. No.9.

Hotmaria. 2021. Upaya Meningkatkan Keterampilan Berbicara Bahasa Inggris Pada Materi Pengandaian Diikuti Perintah/Saran Menggunakan Strategi Pembelajaran Three Step Interview. Journal of Education Action Research,Vol 5, Number 1, Tahun Terbit 2021, pp. $1-9$

Komara, I. B. 2016. Hubungan antara Kepercayaan Diri dengan Prestasi Belajar dan Perencanaan Karir Siswa SMP. PSIKOPEDAGOGIA Jurnal Bimbingan Dan Konseling, 5(1), 33. https://doi.org/10.12928/psikopedagogia.v5i1.4474

Mardatillah. (2010). Pengembangan Diri. STIE Balikpapan: Madani.

Saputra, D. S. 2017. Interactive Learning Dalam Pembelajaran Speaking Di Kelas V Sekolah Dasar. Jurnal Cakrawala Pendas, 3(1). https://doi.org/10.31949/jcp.v3i1.411

Yulianto, Valentia. 2021. Pengaruh Efikasi Diri, Percaya Diri dan Persepsi Penggunaan Media Presentasi terhadap Keterampilan Berbicara Bahasa Mandarin Siswa Kelas 3 SD XYZ. Jurnal Teropong Pendidikan. Volume 1, Edisi 1, Januari 2021, 62-72

(C) 2021 by authors. Content on this article is licensed under a Creative Commons Attribution 4.0 International license. (http://creativecommons.org/licenses/by/4.0/). 